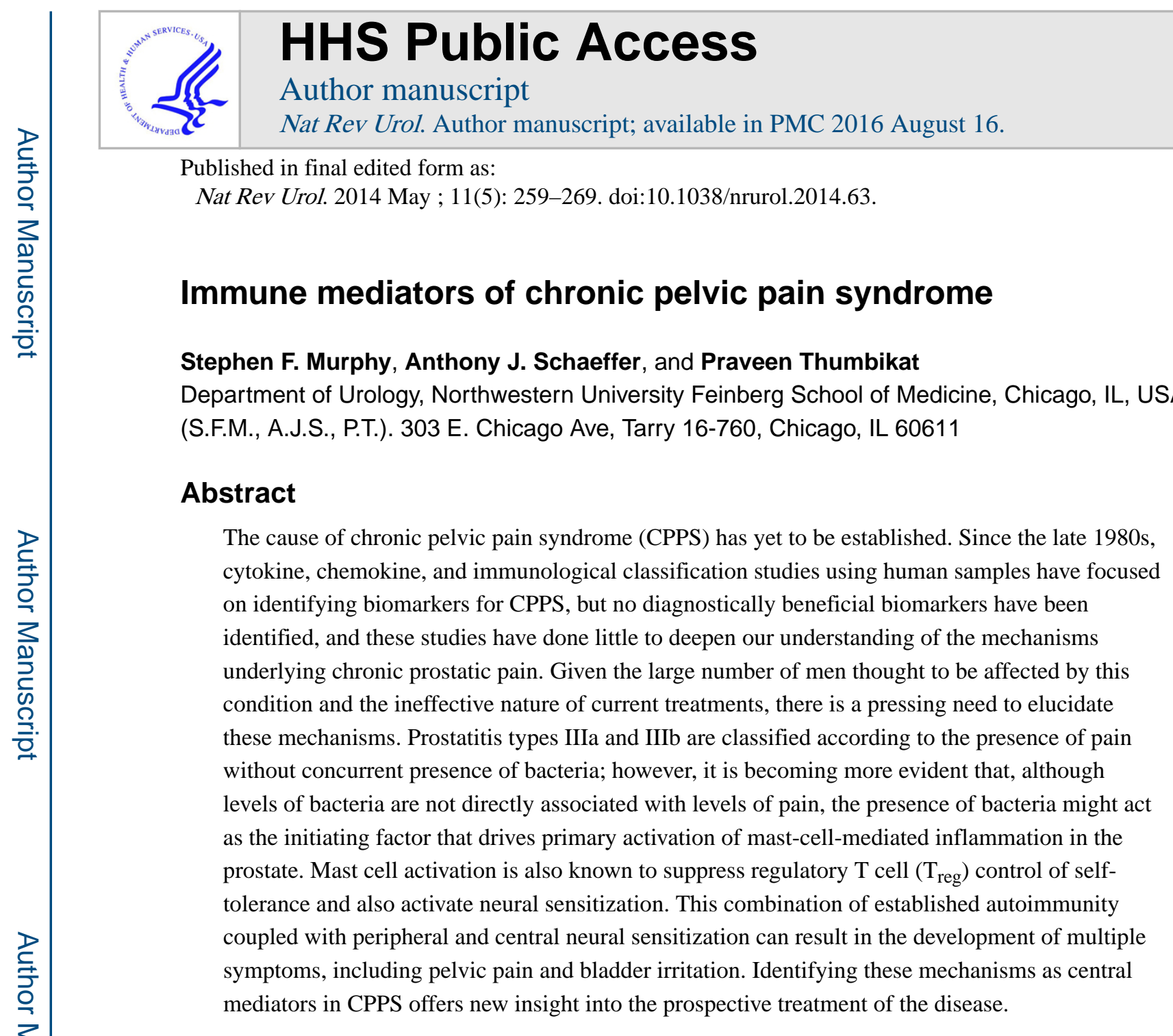

\title{
Introduction
}

Prostatitis (inflammation of the prostate) can be categorized into five different subsets. Of these groups, chronic prostatitis/chronic pelvic pain syndrome (CP/CPPS) is the most common, accounting for $90-95 \%$ of all prostatitis diagnoses. This syndrome is most easily distinguished from the other types of prostatitis by the lack of bacterial association with pain symptoms, which is the case for acute prostatitis (type I) and chronic bacterial prostatitis (type II). ${ }^{1}$ CPPS is further divided by the presence or absence of inflammatory markers in the expressed prostatic secretion (EPS) of affected patients into inflammatory CPPS (type IIIa) and noninflammatory CPPS (type IIIb), ${ }^{1}$ respectively. Finally, the last subset of prostatic disease, asymptomatic prostatitis (type IV), 2,3 is associated with inflammation of the prostate without the emergence of pain symptoms, and is usually diagnosed coincidentally (Box 1).

Competing interests

The authors declare no competing interests.

Author contributions

S.F.M and P.T researched the literature, wrote, edited, and reviewed the article. A.J.S. made substantial contributions towards discussions of contents and reviewed the manuscript prior to submission. 
Box 1

\section{Prostatitis classification}

\section{Type I (acute bacterial prostatitis)}

- $\quad$ Presence of a severe and acute, possibly septic, bacterial infection that is detectable in the urine of patients

- $\quad$ Leukocytes and white blood cells (WBCs) are detectable in expressed prostatic secretion (EPS) $>10 / \mathrm{hpf}$

- $\quad$ Requires immediate medical attention and can be life-threatening, with patients commonly presenting with high levels of pain

\section{Type II (chronic bacterial prostatitis)}

- $\quad$ Nonseptic bacterial infection is detectable in the urine of presenting patients and WBCs are detectable in EPS samples

- $\quad$ Patients might not present with high-level pain but might suffer from intermittent UTI and prostate infection

\section{Type III (chronic pelvic pain syndrome)}

- $\quad$ The most common classification of prostatitis, compromising 90-95\% of diagnoses

- $\quad$ Classified by the absence of detectable bacterial infection at diagnoses with high levels of chronic pain

- $\quad$ Further subcategorized by the presence (type IIIa) or absence (type IIIb) of WBCs in EPS samples

\section{Type IV (asymptomatic inflammatory prostatitis)}

- $\quad$ Patients have no pain and no history of UTI

- $\quad$ WBCs present in EPS

CPPS is a condition with an estimated prevalence rate of up to $15 \%$ of the male population, with most diagnoses occurring between the ages of 35-45 years. ${ }^{2,} 4$ However, incidence varies widely between studies, ranging from $2-16 \%$ of adult men. ${ }^{4,5}$ Studies of large male cohorts of varying ages from Canada, ${ }^{6}$ Australia, ${ }^{7}$ and China ${ }^{8}$ have revealed incidences of $3-8 \%, 2 \%$, and $8.4 \%$, respectively, with average pain scores of 8 and total index scores of approximately $16 .{ }^{9}$ Incidence and symptom severity might vary based on geographic location and ethnicity, but limited data currently support this theory. ${ }^{10}$

Diagnosed by the presence of pain in the absence of bacterial infection for $>3$ months, CPPS has unknown, probably complex, aetiology, which has thus far hampered efforts to determine effective treatment strategies for ameliorating pain. ${ }^{11-13}$ The heterogeneous nature of the symptoms and the length of the disease course prior to detection, presentation, and diagnosis further exacerbate these issues. The complex nature of the disease is reflected 
by the vast array of studies that have been published, ranging from genome-wide association studies (GWAS) to immunological, cell biological, and microbiological investigations. In this article, we collate the disparate published data, enabling a better understanding of the mechanisms behind CPPS and providing insight into ways to enhance the efficacy of treatment.

\section{CPPS symptoms and diagnosis}

CPPS is a complex disease with symptoms that are difficult to both quantify and effectively treat. ${ }^{12-15}$ To overcome these challenges, systems have been developed-such as The National Institute of Health Chronic Prostatitis Symptoms Index (NIH-CPSI) and the Urinary, Psychosocial, Organ Specificity, Infection, Neurologic, and Tenderness (UPOINT) system that help physicians to assess the current and ongoing needs of the patient. ${ }^{2,16,17}$ These systems demonstrate succinctly to researchers the complex nature of the disease and the high degree of variance between patient symptoms. ${ }^{18}$ In doing so, they provide direct avenues of research into the causative effects of CPPS.

The NIH-CPSI was designed to assess the symptoms and quality of life of patients with CPPS,${ }^{19}$ and has been shown to be an effective tool for gauging the effect of chronic pain on morbidity. ${ }^{16,20}$ Using this system, patients are diagnosed with CPPS when they present with perineal or ejaculatory pain and an index score $>4$. However, it is stymied by the fact that, for the most part, it is defined based on a subjective questionnaire and overall scores are determined by a cumulative scoring of symptoms that might or might not be related to one another, or indeed to the underlying causes of pathology. ${ }^{2}$ More recently, the UPOINT system of classification was developed to guide treatment decision-making (Box 2). ${ }^{21}$ Rather than grouping patients based on an aggregate score of symptoms, this system considers each group of symptoms, including urinary ${ }^{22}$, psychosocial $^{23}$, organ-specific, infection, neurological, and tenderness ${ }^{24}$ symptoms, separately (Box 2). ${ }^{20}$ The number of symptom groups involved has been shown to correlate with NIH-CPSI ${ }^{25}$ scores, and multimodal treatment of combinations of symptom groups has been shown to result in decreased scores after 50 weeks of treatment (mean reduction of 12 points), ${ }^{26}$ suggesting that a more individually tailored approach to CPPS might be more effective than a standardized approach. ${ }^{15,18,27-30}$

\section{Box 2}

\section{UPOINT system}

- Urinary problems (specifically irritative or obstructed voiding and urinary tract issues, which might be indicative of interactions between the prostate and the bladder)

- $\quad$ Psychosocial problems (such as clinical depression)

- $\quad$ Organ specificity issues (encompassing a range of problems, such as prostate tenderness and presence of leukocytes in expressed prostatic secretions) 


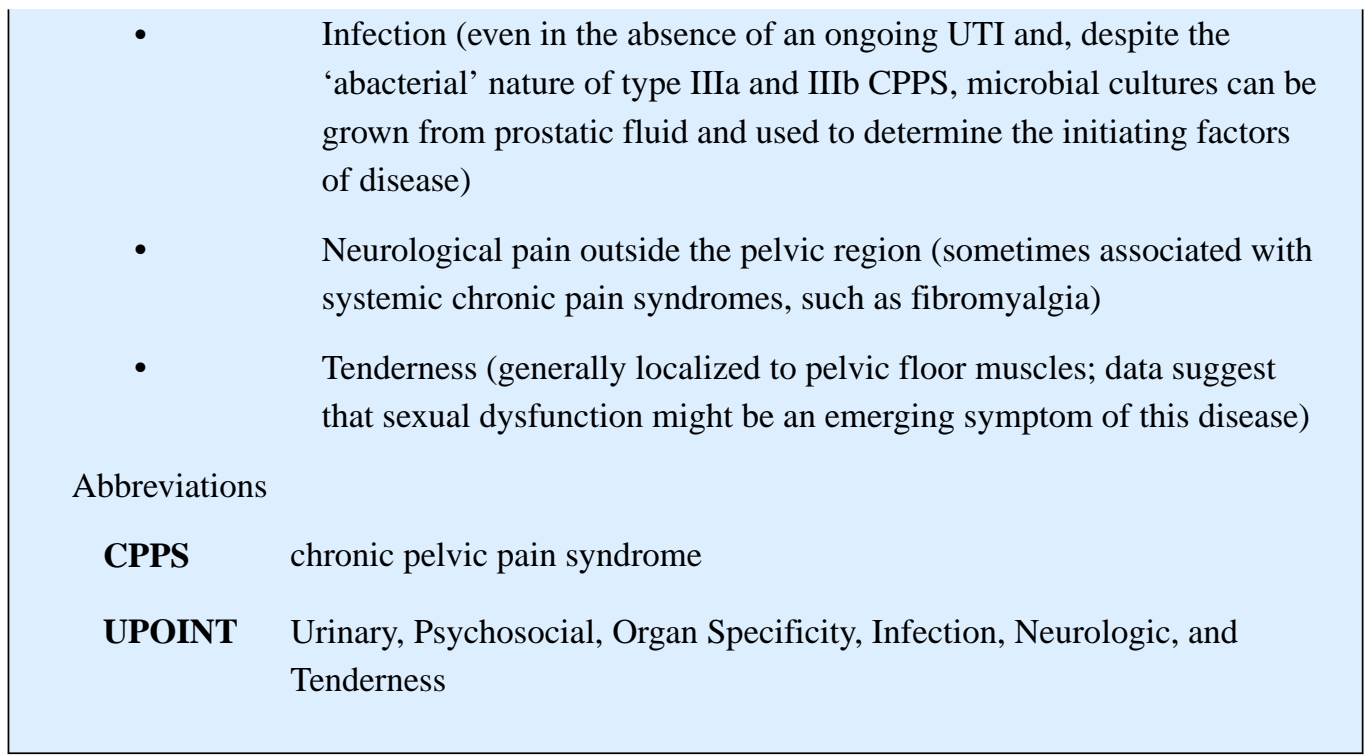

Another issue that has hampered research into the factors causing CPPS is the comorbidity of symptoms. ${ }^{30,31}$ Chronic pain syndromes such as fibromyalgia and chronic fatigue syndrome have been shown to be associated with CPPS, as has irritable bowel syndrome (IBS). ${ }^{32}$ Epidemiological studies have also linked cardiovascular problems to CPPS; in one study, patients with CPPS were six times more likely than controls to have cardiovascular disease, and were also independently shown to have an increased prevalence of arterial stiffness. ${ }^{33,34}$ Assessment of pelvic floor tension, by monitoring the motility of muscles using ultrasonography, linked increased tension to CPPS. ${ }^{35}$ Although there has been some interest in investigating whether pelvic floor tension acts as a causative factor or direct mediator of CPPS, its role in determining patient outcomes has yet to be established. ${ }^{20}$

\section{Infection as an initiating factor}

Distinguishing CPPS from the other types of prostatitis requires evidence of bacterial infection. ${ }^{36-38}$ Although effective for determining patient diagnoses, pinpointing causes of disease using such definitions might not be so clear cut. Studies of the role of bacteria in disease initiation are emerging from our, and other, laboratories, which might be informative for future therapeutic intervention. ${ }^{39-41} \mathrm{We}$ isolated a strain of Escherichia coli, designated CP1, from the EPS of a patient with CPPS and demonstrated that it induced symptoms of pain when introduced into the prostate and urethra of nonobese diabetic (NOD) mice. ${ }^{41}$ NOD mice are genetically distinct from C57BL/6 mice and have been shown to develop spontaneous chronic pain and autoimmune prostatitis over time. Upon prostatic instillation with CP1 bacteria, NOD mice developed bacterial colonization in both the bladder and the prostate, ${ }^{41}$ resulting in chronic pain in the NOD mice that was not detectable (by behavioral tactile allodynia scoring) in C57BL/6 mice. Although the pain symptoms persisted, no bacteria were detectable 35 days after instillation with the microbe, suggesting that infection with $\mathrm{CP} 1$ might initiate disease in genetically susceptible hosts, but that fundamental changes in the immune responses of the prostate are responsible for chronic pain. ${ }^{41} \mathrm{In}$ agreement with this, it is interesting to note that the incidence of chronic inflammatory prostatic disease of noninfectious origin is shown to be eightfold higher than that of bacterial 
prostatitis. ${ }^{41}$ Whether similar models are applicable to humans, such that early infection with a pathogen might cause disease but microbes are undetectable at diagnosis of CPPS, resolving the 'abacterial' definition of CPPS IIIa and IIIb categories of prostatitis, remains to be elucidated.

In addition, the virulence of bacterial isolates was fundamental to the initiation of disease in this mouse study. ${ }^{41}$ Phylogenetic analyses of the CP1 strain identified a group B1 strain of uropathogenic E. coli (UPEC), distinct in both virulence gene and fimbriae expression from the typical group B2 bacteria, which are commonly associated with acute bacterial infection of the urogenital tract. The virulence and invasiveness of CP1 was compared with the typical cystitis-related UPEC group B2 strain NU14. ${ }^{42}$ The authors demonstrated in both in vitro and in vivo systems that, although both bacteria have the same adherence capabilities, CP1 was dramatically more invasive than NU14. ${ }^{41}$ Interestingly, when NU14 is instilled into the prostate of NOD mice, chronic pain does not develop. We are now investigating the possibility that instillation of nonpathogenic strains of atypical urogenital bacteria can reverse pain symptoms in murine models of CPPS. These studies are, at present, only preliminary but seem to indicate that prostatic instillation of certain species of microbiota can reverse inflammation in the prostate and, over time, can significantly reduce pain. ${ }^{43,} 44$ This finding is hoped to lead to the development of probiotic treatments for CPPS in humans.

The immune responses mediating these effects, and leading to the development of pain in the CP1 model, are an area of current investigation. Another bacteria-focused study recently associated Helicobacter pylori infection with CPPS, when patients with CPPS were compared with controls based on antibody seropositivity. ${ }^{45}$ These determinants were not correlated with severity of symptoms and only a relatively small cohort of patients were recruited, so it remains to be seen whether these preliminary findings will affect the development of future therapies. ${ }^{34,45,46}$ The hypothesis that bacterial infection acts as the initiating factor in CPPS is further strengthened by studies demonstrating mixed therapeutic efficacy of antibiotics. ${ }^{38,47}$

\section{Immunological basis of autoimmune activation}

\section{T-cell activation and CP1 infection}

Numerous lines of evidence and ongoing investigations underline the role of the adaptive immune response and activation of autoimmunity in the development of CPPS (Figure 1a and $1 \mathrm{~b}$ ). Inflammation has been shown to have an important role in the development of both prostate cancer and benign prostate hyperplasia (BPH) ${ }^{48-51}$ with studies to show increased levels of the cytokines IL6, IL8, IL15, and IL17 compared with controls. ${ }^{49}$ Generally, the prostate contains only a small number of $\mathrm{CD}^{+} \mathrm{T}$ cells (approximately seven per $\mathrm{mm}^{2}$ of tissue), of which over two-thirds are also $\mathrm{CD} 8^{+}$. These numbers greatly increase with age (to about $55 / \mathrm{mm}^{2}$ in men aged 50 years, correlating with increased rates of benign prostatic disease in ageing men. ${ }^{49}$ The role of inflammation in CPPS pathogenesis is being uncovered using data from both human studies and murine models. Analysis of the immunology behind the CP1 model of chronic pain has demonstrated that $\mathrm{T}$ cells can mediate pelvic pain in the absence of a persistent bacterial infection. ${ }^{52}$ In a recently published article, our lab 
demonstrated CP1-mediated activation of Th1/Th17 CD4 ${ }^{+}$T-cell response and showed that these lymphocytes were sufficient to cause pain upon adoptive transfer to naive uninfected NOD mice. ${ }^{52}$ IL17A, a secreted effector of Th17 cells, was fundamental to the development of pain in the absence of IFN $\gamma$, the main effector of Th1 cells, and pain was increased in IFN $\gamma$ knockout mice upon CP1 instillation. ${ }^{52}$ These results implicate IL17A as an essential mediator in the development of pain, ${ }^{53,54}$ without the need for intact Th1 responses.

Transfer of serum from naive or infected mice did not cause increased pain responses in these mice, indicating that, although there is a strong autoimmune component to this model of CPPS (NOD background only), ${ }^{55}$ no current evidence supports the existence of a systemic circulating antigen or activating factor in this model. ${ }^{52}$

\section{Murine models of prostatitis}

Given the diagnostic value of separating bacterial prostatitis from conditions that are not associated with persistent infection, murine models can offer insight into the alternative mechanisms that might mediate disease progression. Experimental autoimmune prostatitis (EAP) has consistently been linked with underlying immune responses associated with the development of pain in mice. Indeed, this model has been used for the past 20 years to delineate possible mechanisms underlying pathogenesis in humans. ${ }^{56}$ The EAP model of CPPS was first investigated in Wistar rats, but our lab and others use similar models in mice. ${ }^{57}$ Using one such murine model, investigators demonstrated that a particular antigen, prostatic steroid binding protein (PSBP) (also known as prostatein), is capable of inducing EAP when injected with an adjuvant alone, and data suggest that additional antigens might be present in rat prostate homogenates that augment these effects. ${ }^{58-60} \mathrm{In}$ our laboratory, we use a 1:1 ratio of rat prostate homogenate to adjuvant that is injected subcutaneously, and pain is assessed by tactile allodynia after 7 days (for up to 30 days). ${ }^{57}$ Studies of this model in multiple mouse strains have revealed that the development of pain occurs at the highest level, without the need for a second injection of antigen and adjuvant in the NOD background. ${ }^{61}$ NOD mice demonstrate unchecked T-cell immune responses against B-islet cells of the pancreas, resulting in the development of diabetes mellitus. ${ }^{62,63}$ These mice have also been shown to develop autoimmune sialitis, thyroiditis, peripheral neuropathy, systemic lupus erythematosus, and spontaneous prostatitis, and have multiple genetic abnormalities that directly affect their immune systems. Polymorphisms have been identified in IDD3, a gene that controls expression of IL2, an essential cytokine in T-cell development; alterations in the expression pattern of this gene increase the risk of autoimmunity. ${ }^{63} \mathrm{~A}$ second mutation—in CTLA4, a negative regulator of T-effector cell activation-results in incorrect splicing and leads to loss of autoreactive T-cell suppression and development of immune responses against insulin-producing cells. ${ }^{64}$ These data, combined with the high incidence of spontaneous prostatitis in NOD mice, highlight loss of $\mathrm{T}_{\text {reg }}$ suppression as a possible key factor in the development of EAP. ${ }^{63}$

\section{Development of autoimmunity}

D3tx mice have their thymus removed 3 days after birth and develop spontaneous inflammation as a result, ${ }^{65}$ owing, at least in part, to the absence of self-tolerized $\mathrm{T}_{\text {reg }}$ cells (known as natural $\mathrm{T}_{\text {reg }}$ cells), ${ }^{66}$ which form the backbone of central tolerance. ${ }^{67,68}$ Thymic epithelial cells surrounding the thymus control induction of T-cell maturation-and, 
therefore, the development of tolerance-by upregulating expression of the autoimmune regulator (AIRE) ${ }^{69,70}$ transcription factor. AIRE has been shown to regulate expression of, and therefore increase tolerance to, prostate antigens. ${ }^{71,72}$ All AIRE-deficient NOD mice develop inflammation of the prostate by 20 weeks of age, further supporting the loss of tolerance in mouse models of chronic prostatitis. ${ }^{73,74}$ Notably, the spontaneous inflammation observed in D3tx is commonly localized to the prostate, ${ }^{65,75}$ indicating that loss of tolerance to self-prostate antigens has a central role in driving CPPS development. ${ }^{76}$ Peripheral tolerance is also regulated by inducible $T_{\text {reg }}\left(\mathrm{iT}_{\text {reg }}\right)$ cells that mature in a tissuespecific manner in the periphery. ${ }^{77}$ Presentation of antigen from immature dendritic cells in the periphery can induce T-effector cell activation and proliferation in the absence of an $\mathrm{iT}_{\mathrm{reg}}$ response, prompting autoreactive $\mathrm{T}$ cells to drive inflammation in an unchecked manner. ${ }^{78}$ This activation status could explain the immune activation that is commonly seen in murine models of CPPS, with increased number of $\mathrm{CD} 4^{+} \mathrm{T}$ cells leading to increased secretion and expression of IL17 and IFN $\gamma$. Furthermore, a broad analysis of polymorphisms in a variety of immune-regulatory genes, including TGF $\beta$, TNFa, IL10, and IL6, revealed an association between low levels of IL10 production and CPPS, implicating loss of $\mathrm{T}_{\text {reg }}$ function and tolerance as key mediators of inflammation. ${ }^{79} \mathrm{TNFa}$ was also shown to be closely associated with type IIIa CPPS, suggesting that this subtype might have a more proinflammatory phenotype. Failure of treatment with quercetin, ${ }^{80}$ a mast cell stabilizer, in men with CPPS with a more regulatory phenotype is associated with high IL10 and low $\mathrm{TNFa}$ levels, ${ }^{79}$ an interesting observation given that IL10 can regulate and dampen mast cell activity. This finding suggests that mast cells in these patients are already under the regulatory control of IL10, such that further stabilization of degranulation will not ameliorate symptoms.

However, no evidence exists to support spontaneous prostate inflammation in IL10-knockout mice, which suggests that, although activation of autoreactivity might drive CPPS development, mechanisms that are distinct from $\mathrm{iT}_{\text {reg }}$ suppression via IL10 must be responsible for maintaining tolerance in healthy individuals. Furthermore, preliminary data from our laboratory have demonstrated that IL10-knockout mice develop pelvic pain in response to EAP, but instillation with the probiotic bacteria that decreases pain in NOD mice is ineffective in the absence of IL10. These data demonstrate the fundamental role of IL10, not in restraining onset of autoreactivity, but rather controlling it once it has occurred (P. Thumbikat, unpublished work).

\section{Cytokine and chemokine association}

\section{Human studies}

Since the late 1980s, numerous studies have aimed to establish an association between expression of certain immunomodulatory proteins and numbers of particular cell types in samples from men with CPPS. Analysis of these samples, which have been taken from various urogenital and systemic sources including EPS, seminal plasma, postprostatic massage urine, and semen, has demonstrated increased levels of numerous proinflammatory cytokines, including, IL1b, TNFa, IL6, Il8, and $\operatorname{IgA},{ }^{81-87}$ as well as decreased levels of IL2R (involved in T-cell development) in patients with CPPS compared with controls. 
Studies involving multiple sample types (including EPS, postprostatic massage urine, and semen) have shown increased numbers of granulocytes, macrophages, and both activated $\mathrm{T}$ cells and B lymphocytes in the cellular infiltrate of patients with CPPS. ${ }^{88}$ Prostate inflammation has also been examined histologically, ${ }^{3}$ with data to show increased leukocyte infiltration and increased numbers of $\mathrm{T}$ cells (more specifically, $\mathrm{CD} 8^{+} \mathrm{T}$ cells) compared with controls. ${ }^{89}$

The T-cell immune response to prostate antigens has also been investigated and CD4 T cells have been shown to respond to seminal plasma from patients in two independent studies. ${ }^{90,91}$ Moreover, IFN $\gamma$-producing Th1 cells have been identified in the peripheral blood of men with CPPS that are specific to PSA. ${ }^{92,93}$ High PSA levels in blood are commonly associated with prostate tissue damage and carcinogenesis. ${ }^{94}$ A similar study identified $\operatorname{Ig} \mathrm{A}$ antibodies that are specific to two additional prostate antigens, MAD-PRO-34 and Ny-Co-7, in patients with CPPS. ${ }^{95}$ These studies, and others, point to autoreactivity to prostate antigens as a potential driver of CPPS and support the existence of organ-resident autoreactive T cells, which become activated following an initiation event. ${ }^{84}$

\section{MCP1 and MIP1a}

Two chemokines have been associated with the development and progression of pain in multiple studies of CPPS.${ }^{96}$ Monocyte chemotactic protein 1 (MCP1) ${ }^{97}$ also known as chemokine C-C motif ligand 2 (CCL2), ${ }^{98}$ is a chemotactic factor that attracts monocytes and basophils to sites of inflammation and is implicated in the pathogenesis of numerous autoimmune diseases, including rheumatoid arthritis, ${ }^{99}$ aortic aneurysms, ${ }^{100}$ and coronary artery disease. ${ }^{101}$ Macrophage inflammation protein 1a (MIP1a), ${ }^{99,} 102$ also known as chemokine C-C motif ligand 3 (CCL3), ${ }^{103,} 104$ is a potent inducer of proinflammatory responses and has been shown to be upregulated in patients with rheumatoid arthritis, systemic lupus erythematosus, and ulcerative colitis. Levels of both chemokines are elevated in EPS samples from men with type IIIa and type IIIb CPPS compared with those with BPH and healthy controls. ${ }^{105}$ It was hypothesized that, although type IIIlb CPPS (noninflammatory) is categorized as a distinct subset of disease from type IIIa, it might, in fact, represent a distinct snapshot in the natural course of the disease when inflammation is ongoing but neutrophilic infiltration has yet to start. In the same study, levels of MIP1a, but not MCP1, positively correlated with National Institutes of Health Chronic Prostatitis Symptom Index (NIH-CPSI) pain score in patients. MCP1 was, however, positively correlated with the number of white blood cells in EPS samples, ${ }^{105}$ indicating that, although levels of both chemokines are increased in CPPS samples, each chemokine might have distinct effects in terms of mediating different symptoms of CPPS. ${ }^{106}$

Another, more-recent, study from our laboratory also investigated CCL2 and CCL3 as potential biomarkers for CPPS using the murine EAP model. This study assessed the source, nature, and kinetics of chemokine expression and the phenotype of the associated immune infiltrate. ${ }^{107}$ The results highlighted important roles for CCL2 and CCL3 in the pathogenesis of pelvic pain in EAP. Increases in CCL2 in prostate tissue were shown at the mRNA level at day 5 and day 20 after EAP; CCL3 increases were observed at day 20. Prostatic epithelial cells expressed the highest levels of CCL2 and CCL3, and were identified as the main source 
of both chemokines in EAP-treated prostates. ${ }^{107}$ Expression levels of these cytokines were significantly elevated in the stroma of EAP-treated prostate tissue compared with control tissue. These differences were confirmed using immunohistochemical analysis, which demonstrated increased expression of CCL2 and CCL3 in the epithelial compartment and increased expression of another chemokine, CCL12, in the stroma. ${ }^{107}$ The effect of these expression changes on cellular infiltrate was also examined and numbers of various cell types; CD4 T cells were decreased at days 5 and 10, but increased at day 20, CD8 T cells were decreased at each time point after day 0 , mast cells were increased at days 5 and 10 , macrophage and neutrophils increased at day 10 and B cells at days 5 and $10 .{ }^{107}$ Although a plethora of studies have attempted to define a biomarker for CPPS, few have used the resulting data to delineate a functional consequence for altered levels of certain cytokines or chemokines. However, the investigators in this study were able to demonstrate the functional consequences of changing the cellular milieu of mice undergoing EAP. Currently, studies are underway to identify the role of these chemokines in mediating neuroinflammation and neuropathic pain in murine models of CPPS.

Numerous studies using high-throughput arrays to measure cytokine and chemokine levels in EPS samples from patients with CPPS are underway. One such preliminary study from our laboratory has revealed positive correlations between levels of a known mediator of Tcell immunity with each of the three metrics used to categorize symptoms in patients, including the pain subscale, urinary subscale, and quality of life. Expression levels of this cytokine are currently being investigated in various mouse models of prostatitis ( $\mathrm{P}$. Thumbikat, unpublished work), ${ }^{108}$ hopefully leading to a greater understanding of how the cytokine and chemokine milieu leads to progression of disease.

\section{Mast cells}

\section{Tryptase and cellular function}

Mast cells have become a major focus of current research, with proposed roles as the main mediator and effector cells in disease progression from initiation to breaking of tolerance, neuronal activation, and, eventually, sensitization. ${ }^{109,110}$ Mast cells are derived from CD34 ${ }^{+}$ haematopoietic precursor cells in bone marrow; they circulate as immature cells, only fully maturing once they are resident at a specific tissue or site, where they become activated. This process suggests a tissue-specific or organ-specific cell phenotype. ${ }^{111}$ Mast cells are also thought to be the first line of defense against infection by microbes and are usually located in (or near to) blood or lymphatic vessels and nerves. ${ }^{110,111}$ They demonstrate both protective and pathological effects in a context-dependent manner, with roles in wound healing, angiogenesis, and inflammation. ${ }^{110,111}$ Crosslinking of their IgE receptor leads to cell sensitization (as seen in conditions such as asthma). Upon activation, mast cells release several molecules stored in granules, including histamine, serotonin, tryptase, chymase, prostaglandin D2 (PGD2), and leukotriene B4, triggering early-stage allergic responses. ${ }^{112-114}$ Aside from the effect of IgE crosslinking, activation of mast cells is classified as nonallergic and can originate from a diverse range of sources including pathogen-associated molecular patterns, complement, cytokines, drugs, hormones, and physical stressors such as temperature and pressure. ${ }^{110,111}$ Mast cells can also directly 
interact with $\mathrm{T}$ cells and $\mathrm{B}$ cells via antigen presentation and can also be involved in reverse signalling, particularly through CD40 and CD40L ligands. ${ }^{115}$ Finally, mast cells have also been shown to mediate signals related to TNFa stimulation in order to control neutrophilic recruitment. ${ }^{116}$

\section{Mast cells and inflammatory conditions}

In order to assess the role of mast cells in CPPS, it is useful to draw parallels between their functions in other chronic inflammatory pain disorders and establish whether these functions can also be attributed to the development of CPPS. Experimental autoimmune encephalopathy results from a breach of the blood brain barrier, which allows infiltration of immune cells into the central nervous system. ${ }^{117,}{ }^{118}$ Encephalogenic CD4 ${ }^{+}$IFN $\gamma$-producing Th1 cells are the major contributor to the pathogenic autoimmune response. ${ }^{119,}{ }^{120}$ IL17aproducing Th17 cells and IL9-producing Th9 cells have been shown to have major roles in the development of experimental autoimmune encephalopathy. ${ }^{121119}$ Patients with multiple sclerosis display increases in mast cell numbers at sites of inflammatory demyelination, ${ }^{122}$ and increased levels of tryptase in their cerebrospinal fluid. ${ }^{123}$ In vitro analyses have revealed that mast cell proteases are also capable of degrading myelin, further implicating mast cells and mast cell degranulation in the progression of this debilitating disease. ${ }^{124-126}$ Mast cells are also associated with rheumatoid arthritis, a chronic systemic autoimmune disease that results in loss of mobility and flexibility of synovial joints. ${ }^{112,} 127$ Increased numbers of mast cells and secreted tryptase have been found at affected synovial joints and in synovial fluid, respectively. ${ }^{128,}{ }^{129}$ Increased levels of proinflammatory cytokines, such as IL6, IL17, and TNFa, have also been associated with rheumatoid arthritis and mast cells have been identified as the main source of IL17 expression. ${ }^{130,131}$

Mast cells have been shown to mediate both $\mathrm{T}_{\text {reg }}$ and Th17 cells, and are consistently found in close proximity to secondary lymphoid organs. ${ }^{132}$ The best-defined mast: T-reg cellular interaction is between the OX40 receptor expressed by $\mathrm{T}_{\text {reg }}$ and OX40L ligand expressed by mast cells. ${ }^{133,134}$. Activation of $\mathrm{T}_{\text {reg }}$ cells have been shown to result in decreased levels of FceR1 receptors on mast cells, thus preventing IgE crosslinking and degranulation in allergic responses. Mast cells, on the other hand, can decrease suppression of T-effector cells by $\mathrm{T}_{\text {reg }}$ cells and can also reduce the susceptibility of these cells to suppression. ${ }^{135}$ Mast cells express a variety of cytokines at high levels including IL6, IL21, IL23, and TGF $\beta,{ }^{136}$ all of which have been shown, in various combinations, to control naive $\mathrm{Th} 17 / \mathrm{T}_{\text {reg }}$ cell differentiation and plasticity. ${ }^{136}$

EPS samples from men with CPPS have been shown to have increased levels of both mast cell number and mast cell tryptase content compared with controls. ${ }^{137}$ Furthermore, mastcell-deficient $\mathrm{Kit}^{\mathrm{W}}{ }^{\mathrm{Sh}} / \mathrm{Kit}^{\mathrm{W}}{ }^{\mathrm{S}} \mathrm{sh}$ Sash mice have attenuated pain responses (tactile allodynia) upon induction of EAP, but exhibit no difference in levels of inflammatory infiltrate, ${ }^{126,138}$ suggesting that, although mast cells are important for the development of CPPS, additional mediators of pain might be present, in both humans and mice, that account for the increased numbers of cytokines and lymphocytes in tissues of affected individuals. Current studies in our laboratory focus on the role of mast cell tryptase in mediating pain in murine EAP, specifically through the protease-activated receptor 2 (PAR2) receptor, a potent mediator of 
innate and adaptive immune responses. ${ }^{139}$ These data implicate the PAR2 signalling network as being fundamental for the development of chronic inflammation and pain.

\section{Neuronal mechanisms}

Mast cells contribute to rapidly occurring neuronal peripheral sensitization, ${ }^{140}$ which is mediated by the neurotrophin nerve growth factor (NGF). ${ }^{141-143}$ Mast cells are known to express TrkA receptors on their cell membrane and, therefore, NGF binding might cause degranulation, establishing a feedback mechanism that would promote sensitization mechanisms. As peripheral tissue insults are often associated with some degree of nerve damage, increased levels of NGF might be produced as the tissue regenerates. In men with CPPS, NGF levels are elevated in seminal plasma and directly correlated with pain severity. ${ }^{144}$ This intriguing result suggests the existence of underlying peripheral sensitization mechanisms in CPPS, with NGF and mast cell proteases as potential mediators. Increased NGF expression is known to increase neuronal excitability and enhance neuronal density in peripheral tissues. In this context, previous work has demonstrated increased neuronal density in prostate tissue sections from animal models of prostatitis. ${ }^{57}$ These results suggest that peripheral sensitization mediated through NGF (and potentially involving mast cell activation) might underlie chronic pelvic pain.

In addition to, or as a consequence of, persistent peripheral neuronal activation, it is thought that changes in the spinal cord might occur in places where persistent activation of spinal cord neurons enhances pain responses. Persistent activation causes alteration in the dorsal horn of the spinal cord, where nociceptor paths enter the central nervous system. Changes include enhanced expression of neurotransmitter receptors (such as N-methyl-D-aspartate receptor), increased neurotransmitter biosynthesis and release, and the sprouting of nociceptor neurons. ${ }^{145}$ Sustained nociceptor firing results in progressive amplification of dorsal horn neuron activity, which can either remain restricted to the activated synapse or spread to adjacent synapses. This hypersensitivity of dorsal horn neurons can mediate pain after the peripheral damage has healed. Thus, central sensitization within the spinal cord of patients with CPPS could mediate pain long after the resolution of any prostate inflammation or other pelvic insult that might initiate symptoms.

\section{Conclusions}

CPPS is a complex syndrome of unknown aetiology; thus, uncovering and implementing effective treatments has so far proven difficult. It is our hypothesis, however, that an initiating event, such as a bacterial infection, activates the prostatic immune response in an unchecked manner. A large amount of evidence suggests that loss of regulation of autoreactive $\mathrm{T}$ cells has a fundamental role in driving pathogenesis. This loss of regulation amounts to a breaking of tolerance to normal prostatic antigens (self, bacterial, or otherwise), further exacerbation of an adaptive proinflammatory immune response, and development of neural sensitization. We propose that these events are mediated through mast cells, by a variety of cytokines, chemokines, and cellular effectors such as tryptase.

Activation of these responses can prevent normal regulation of activated $\mathrm{T}$ cells, resulting in autoimmunity and unchecked inflammation, especially in a genetically susceptible host. An 
open question that remains, however, relates to the role of neural sensitization. Although we, and others, think this effect is also likely to be driven by mast cells, given the chronic nature of patient pain, it is not yet known whether removal of the inflammatory stimulus can reverse neural changes. Resolving these issues would improve our understanding of therapies for men with CPPS, which we believe should focus, at least in part, on restoration of immune balance and tolerance within the prostate.

\section{Supplementary Material}

Refer to Web version on PubMed Central for supplementary material.

\section{References}

1. Krieger JN, Nyberg L Jr, Nickel JC. NIH consensus definition and classification of prostatitis. JAMA. 1999; 282:236-7. [PubMed: 10422990]

2. Mahal BA, et al. The role of phenotyping in chronic prostatitis/chronic pelvic pain syndrome. Curr Urol Rep. 2011; 12:297-303. [PubMed: 21533747]

3. True LD, Berger RE, Rothman I, Ross SO, Krieger JN. Prostate histopathology and the chronic prostatitis/chronic pelvic pain syndrome: a prospective biopsy study. J Urol. 1999; 162:2014-8. [PubMed: 10569559]

4. Collins MM, et al. Prevalence and correlates of prostatitis in the health professionals follow-up study cohort. J Urol. 2002; 167:1363-6. [PubMed: 11832733]

5. Nickel JC, Downey J, Hunter D, Clark J. Prevalence of prostatitis-like symptoms in a population based study using the National Institutes of Health chronic prostatitis symptom index. J Urol. 2001; 165:842-5. [PubMed: 11176483]

6. Tripp DA, Nickel JC, Ross S, Mullins C, Stechyson N. Prevalence, symptom impact and predictors of chronic prostatitis-like symptoms in Canadian males aged 16-19 years. BJU Int. 2009; 103:1080-4. [PubMed: 19007369]

7. Ferris JA, et al. National prevalence of urogenital pain and prostatitis-like symptoms in Australian men using the National Institutes of Health Chronic Prostatitis Symptoms Index. BJU Int. 2010; 105:373-9. [PubMed: 19549116]

8. Liang CZ, et al. The prevalence of prostatitis-like symptoms in China. J Urol. 2009; 182:558-63. [PubMed: 19524948]

9. Mehik A, Hellstrom P, Lukkarinen O, Sarpola A, Jarvelin M. Epidemiology of prostatitis in Finnish men: a population-based cross-sectional study. BJU Int. 2000; 86:443-8. [PubMed: 10971269]

10. Schaeffer AJ. Epidemiology and evaluation of chronic pelvic pain syndrome in men. Int $\mathbf{J}$ Antimicrob Agents. 2008; 31(Suppl 1):S108-11. [PubMed: 18164597]

11. Ku JH, Kim SW, Paick JS. Quality of life and psychological factors in chronic prostatitis/chronic pelvic pain syndrome. Urology. 2005; 66:693-701. [PubMed: 16230119]

12. Konkle KS, Clemens JQ. New paradigms in understanding chronic pelvic pain syndrome. Curr Urol Rep. 2011; 12:278-83. [PubMed: 21448731]

13. Pontari M, Giusto L. New developments in the diagnosis and treatment of chronic prostatitis/ chronic pelvic pain syndrome. Curr Opin Urol. 2013; 23:565-9. [PubMed: 24080807]

14. Schaeffer AJ. Etiology and management of chronic pelvic pain syndrome in men. Urology. 2004; 63:75-84. [PubMed: 15013657]

15. Motrich RD, et al. Reduced semen quality in chronic prostatitis patients that have cellular autoimmune response to prostate antigens. Hum Reprod. 2005; 20:2567-72. [PubMed: 15890732]

16. Wagenlehner FM, et al. National Institutes of Health Chronic Prostatitis Symptom Index (NIHCPSI) symptom evaluation in multinational cohorts of patients with chronic prostatitis/chronic pelvic pain syndrome. Eur Urol. 2013; 63:953-9. [PubMed: 23141933]

17. Walz J, et al. Impact of chronic prostatitis-like symptoms on the quality of life in a large group of men. BJU Int. 2007; 100:1307-11. [PubMed: 17941922] 
18. Davis SN, Binik YM, Amsel R, Carrier S. A subtype based analysis of urological chronic pelvic pain syndrome in men. J Urol. 2013; 190:118-23. [PubMed: 23321578]

19. Le BV, Schaeffer AJ. Genitourinary pain syndromes, prostatitis, and lower urinary tract symptoms. Urol Clin North Am. 2009; 36:527-36. vii. [PubMed: 19942050]

20. Anderson RU, Wise D, Sawyer T, Chan CA. Sexual dysfunction in men with chronic prostatitis/ chronic pelvic pain syndrome: improvement after trigger point release and paradoxical relaxation training. J Urol. 2006; 176:1534-8. discussion 1538-9. [PubMed: 16952676]

21. Magri V, et al. Use of the UPOINT chronic prostatitis/chronic pelvic pain syndrome classification in European patient cohorts: sexual function domain improves correlations. J Urol. 2010; 184:2339-45. [PubMed: 20952019]

22. Kaplan SA, et al. Etiology of voiding dysfunction in men less than 50 years of age. Urology. 1996; 47:836-9. [PubMed: 8677573]

23. Kwon JK, Chang IH. Pain, catastrophizing, and depression in chronic prostatitis/chronic pelvic pain syndrome. Int Neurourol J. 2013; 17:48-58. [PubMed: 23869268]

24. Anderson RU, Sawyer T, Wise D, Morey A, Nathanson BH. Painful myofascial trigger points and pain sites in men with chronic prostatitis/chronic pelvic pain syndrome. J Urol. 2009; 182:2753-8. [PubMed: 19837420]

25. Hedelin HH. Evaluation of a modification of the UPOINT clinical phenotype system for the chronic pelvic pain syndrome. Scand J Urol Nephrol. 2009; 43:373-6. [PubMed: 19921982]

26. Shoskes DA, Nickel JC, Kattan MW. Phenotypically directed multimodal therapy for chronic prostatitis/chronic pelvic pain syndrome: a prospective study using UPOINT. Urology. 2010; 75:1249-53. [PubMed: 20363491]

27. Nickel JC, Shoskes DA. Phenotypic approach to the management of the chronic prostatitis/chronic pelvic pain syndrome. BJU Int. 2010; 106:1252-63. [PubMed: 20946349]

28. Potts JM, Payne CK. Urologic chronic pelvic pain. Pain. 2012; 153:755-8. [PubMed: 22153018]

29. Tugcu V, et al. A placebo-controlled comparison of the efficiency of triple- and monotherapy in category III B chronic pelvic pain syndrome (CPPS). Eur Urol. 2007; 51:1113-7. discussion 1118. [PubMed: 17084960]

30. Baranowski AP. Urogenital/pelvic pain in men. Curr Opin Support Palliat Care. 2012; 6:213-9. [PubMed: 22436320]

31. Rodriguez MA, et al. Evidence for overlap between urological and nonurological unexplained clinical conditions. J Urol. 2009; 182:2123-31. [PubMed: 19758633]

32. Samplaski MK, Li J, Shoskes DA. Clustering of UPOINT domains and subdomains in men with chronic prostatitis/chronic pelvic pain syndrome and contribution to symptom severity. J Urol. 2012; 188:1788-93. [PubMed: 22998916]

33. Shoskes DA, Prots D, Karns J, Horhn J, Shoskes AC. Greater endothelial dysfunction and arterial stiffness in men with chronic prostatitis/chronic pelvic pain syndrome--a possible link to cardiovascular disease. J Urol. 2011; 186:907-10. [PubMed: 21791354]

34. Mendall MA, et al. Relation of Helicobacter pylori infection and coronary heart disease. Br Heart J. 1994; 71:437-9. [PubMed: 8011406]

35. Khorasani B, Arab AM, Sedighi Gilani MA, Samadi V, Assadi H. Transabdominal ultrasound measurement of pelvic floor muscle mobility in men with and without chronic prostatitis/chronic pelvic pain syndrome. Urology. 2012; 80:673-7. [PubMed: 22925244]

36. Rudick CN, et al. Host-pathogen interactions mediating pain of urinary tract infection. J Infect Dis. 2010; 201:1240-9. [PubMed: 20225955]

37. Motrich RD, Cuffini C, Oberti JP, Maccioni M, Rivero VE. Chlamydia trachomatis occurrence and its impact on sperm quality in chronic prostatitis patients. J Infect. 2006; 53:175-83. [PubMed: 16376990]

38. Wagenlehner FM, et al. Bacterial prostatitis. World J Urol. 2013; 31:711-6. [PubMed: 23519458]

39. Doble A, et al. The role of Chlamydia trachomatis in chronic abacterial prostatitis: a study using ultrasound guided biopsy. J Urol. 1989; 141:332-3. [PubMed: 2643724]

40. Doble A, et al. A search for infectious agents in chronic abacterial prostatitis using ultrasound guided biopsy. Br J Urol. 1989; 64:297-301. [PubMed: 2679961] 
41. Rudick CN, et al. Uropathogenic Escherichia coli induces chronic pelvic pain. Infect Immun. 2011; 79:628-35. [PubMed: 21078846]

42. Sivick KE, Schaller MA, Smith SN, Mobley HL. The innate immune response to uropathogenic Escherichia coli involves IL-17A in a murine model of urinary tract infection. J Immunol. 2010; 184:2065-75. [PubMed: 20083670]

43. Huang BR, et al. Interaction of inflammatory and anti-inflammatory responses in microglia by Staphylococcus aureus-derived lipoteichoic acid. Toxicol Appl Pharmacol. 2013; 269:43-50. [PubMed: 23500011]

44. Myles IA, et al. Signaling via the IL-20 receptor inhibits cutaneous production of IL-1beta and IL-17A to promote infection with methicillin-resistant Staphylococcus aureus. Nat Immunol. 2013; 14:804-11. [PubMed: 23793061]

45. Karatas OF, Bayrak O, Cimentepe E, Unal D. An occult risk factor for chronic prostatitis: Helicobacter pylori. Med Hypotheses. 2007; 69:963-4. [PubMed: 17412518]

46. Karatas OF, Turkay C, Bayrak O, Cimentepe E, Unal D. Helicobacter pylori seroprevalence in patients with chronic prostatitis: a pilot study. Scand J Urol Nephrol. 2010; 44:91-4. [PubMed: 20163196]

47. Tomaskovic I, Ruzic B, Trnski D, Kraus O. Chronic prostatitis/chronic pelvic pain syndrome in males may be an autoimmune disease, potentially responsive to corticosteroid therapy. Med Hypotheses. 2009; 72:261-2. [PubMed: 19095365]

48. Theyer G, et al. Phenotypic characterization of infiltrating leukocytes in benign prostatic hyperplasia. Lab Invest. 1992; 66:96-107. [PubMed: 1370561]

49. Steiner G, et al. Phenotype and function of peripheral and prostatic lymphocytes in patients with benign prostatic hyperplasia. J Urol. 1994; 151:480-4. [PubMed: 7506795]

50. Bierhoff E, et al. Morphological analogies of fetal prostate stroma and stromal nodules in BPH. Prostate. 1997; 31:234-40. [PubMed: 9180933]

51. Kramer G, et al. Increased expression of lymphocyte-derived cytokines in benign hyperplastic prostate tissue, identification of the producing cell types, and effect of differentially expressed cytokines on stromal cell proliferation. Prostate. 2002; 52:43-58. [PubMed: 11992619]

52. Quick ML, et al. Th1-Th17 cells contribute to the development of uropathogenic Escherichia coliinduced chronic pelvic pain. PLoS One. 2013; 8:e60987. [PubMed: 23577183]

53. Carlson T, Kroenke M, Rao P, Lane TE, Segal B. The Th17-ELR+ CXC chemokine pathway is essential for the development of central nervous system autoimmune disease. J Exp Med. 2008; 205:811-23. [PubMed: 18347102]

54. Zhang HL, Zheng XY, Zhu J. Th1/Th2/Th17/Treg cytokines in Guillain-Barre syndrome and experimental autoimmune neuritis. Cytokine Growth Factor Rev. 2013; 24:443-53. [PubMed: 23791985]

55. Zielinski CE, et al. Pathogen-induced human TH17 cells produce IFN-gamma or IL-10 and are regulated by IL-1beta. Nature. 2012; 484:514-8. [PubMed: 22466287]

56. Motrich RD, Maccioni M, Riera CM, Rivero VE. Autoimmune prostatitis: state of the art. Scand J Immunol. 2007; 66:217-27. [PubMed: 17635799]

57. Rudick CN, Schaeffer AJ, Thumbikat P. Experimental autoimmune prostatitis induces chronic pelvic pain. Am J Physiol Regul Integr Comp Physiol. 2008; 294:R1268-75. [PubMed: 18287220]

58. Maccioni M, Rivero VE, Riera CM. Prostatein (or rat prostatic steroid binding protein) is a major autoantigen in experimental autoimmune prostatitis. Clin Exp Immunol. 1998; 112:159-65. [PubMed: 9649176]

59. Rivero V, Carnaud C, Riera CM. Prostatein or steroid binding protein (PSBP) induces experimental autoimmune prostatitis (EAP) in NOD mice. Clin Immunol. 2002; 105:176-84. [PubMed: 12482391]

60. Penna G, et al. Spontaneous and prostatic steroid binding protein peptide-induced autoimmune prostatitis in the nonobese diabetic mouse. J Immunol. 2007; 179:1559-67. [PubMed: 17641022]

61. Rivero VE, Cailleau C, Depiante-Depaoli M, Riera CM, Carnaud C. Non-obese diabetic (NOD) mice are genetically susceptible to experimental autoimmune prostatitis (EAP). J Autoimmun. 1998; 11:603-10. [PubMed: 9878082] 
62. Louvet $\mathrm{C}$, et al. Tyrosine kinase inhibitors reverse type 1 diabetes in nonobese diabetic mice. Proc Natl Acad Sci U S A. 2008; 105:18895-900. [PubMed: 19015530]

63. Gallegos AM, Bevan MJ. Driven to autoimmunity: the nod mouse. Cell. 2004; 117:149-51. [PubMed: 15084253]

64. Kim JM, Rudensky A. The role of the transcription factor Foxp3 in the development of regulatory T cells. Immunol Rev. 2006; 212:86-98. [PubMed: 16903908]

65. Bonomo A, Kehn PJ, Shevach EM. Post-thymectomy autoimmunity: abnormal T-cell homeostasis. Immunol Today. 1995; 16:61-7. [PubMed: 7888068]

66. Taguchi O, Nishizuka Y. Self tolerance and localized autoimmunity. Mouse models of autoimmune disease that suggest tissue-specific suppressor T cells are involved in self tolerance. J Exp Med. 1987; 165:146-56. [PubMed: 2432148]

67. Gallegos AM, Bevan MJ. Central tolerance: good but imperfect. Immunol Rev. 2006; 209:290-6. [PubMed: 16448550]

68. Gallegos AM, Bevan MJ. Central tolerance to tissue-specific antigens mediated by direct and indirect antigen presentation. J Exp Med. 2004; 200:1039-49. [PubMed: 15492126]

69. Anderson MS, et al. Projection of an immunological self shadow within the thymus by the aire protein. Science. 2002; 298:1395-401. [PubMed: 12376594]

70. Rizzi M, Ferrera F, Filaci G, Indiveri F. Disruption of immunological tolerance: role of AIRE gene in autoimmunity. Autoimmun Rev. 2006; 5:145-7. [PubMed: 16431348]

71. Ferrera F, et al. AIRE gene polymorphisms in systemic sclerosis associated with autoimmune thyroiditis. Clin Immunol. 2007; 122:13-7. [PubMed: 17101293]

72. Anderson MS, et al. The cellular mechanism of Aire control of T cell tolerance. Immunity. 2005; 23:227-39. [PubMed: 16111640]

73. Villasenor J, Benoist C, Mathis D. AIRE and APECED: molecular insights into an autoimmune disease. Immunol Rev. 2005; 204:156-64. [PubMed: 15790357]

74. Kim JM, Rasmussen JP, Rudensky AY. Regulatory T cells prevent catastrophic autoimmunity throughout the lifespan of mice. Nat Immunol. 2007; 8:191-7. [PubMed: 17136045]

75. Taguchi O, Kojima A, Nishizuka Y. Experimental autoimmune prostatitis after neonatal thymectomy in the mouse. Clin Exp Immunol. 1985; 60:123-9. [PubMed: 4006298]

76. Bonomo A, et al. Pathogenesis of post-thymectomy autoimmunity. Role of syngeneic MLRreactive T cells. J Immunol. 1995; 154:6602-11. [PubMed: 7759894]

77. Setiady YY, et al. Physiologic self antigens rapidly capacitate autoimmune disease-specific polyclonal CD4+ CD25+ regulatory T cells. Blood. 2006; 107:1056-62. [PubMed: 16223778]

78. de Vries VC, et al. Mast cell degranulation breaks peripheral tolerance. Am J Transplant. 2009; 9:2270-80. [PubMed: 19681828]

79. Shoskes DA, Albakri Q, Thomas K, Cook D. Cytokine polymorphisms in men with chronic prostatitis/chronic pelvic pain syndrome: association with diagnosis and treatment response. $\mathbf{J}$ Urol. 2002; 168:331-5. [PubMed: 12050565]

80. Shoskes DA, Nickel JC. Quercetin for chronic prostatitis/chronic pelvic pain syndrome. Urol Clin North Am. 2011; 38:279-84. [PubMed: 21798389]

81. John $\mathrm{H}$, et al. Noninflammatory chronic pelvic pain syndrome: immunological study in blood, ejaculate and prostate tissue. Eur Urol. 2001; 39:72-8. [PubMed: 11173942]

82. Penna G, et al. Seminal plasma cytokines and chemokines in prostate inflammation: interleukin 8 as a predictive biomarker in chronic prostatitis/chronic pelvic pain syndrome and benign prostatic hyperplasia. Eur Urol. 2007; 51:524-33. discussion 533. [PubMed: 16905241]

83. Orhan I, Onur R, Ilhan N, Ardicoglu A. Seminal plasma cytokine levels in the diagnosis of chronic pelvic pain syndrome. Int J Urol. 2001; 8:495-9. [PubMed: 11683970]

84. Motrich RD, et al. Pathogenic consequences in semen quality of an autoimmune response against the prostate gland: from animal models to human disease. J Immunol. 2006; 177:957-67. [PubMed: 16818751]

85. Khadra A, Fletcher P, Luzzi G, Shattock R, Hay P. Interleukin-8 levels in seminal plasma in chronic prostatitis/chronic pelvic pain syndrome and nonspecific urethritis. BJU Int. 2006; 97:1043-6. [PubMed: 16643489] 
86. John H, et al. Immunological alterations in the ejaculate of chronic prostatitis patients: clues for autoimmunity. Andrologia. 2003; 35:294-9. [PubMed: 14535858]

87. Ludwig M, et al. Immunocytological analysis of leukocyte subpopulations in urine specimens before and after prostatic massage. Eur Urol. 2001; 39:277-82. [PubMed: 11275719]

88. Nickel JC, et al. Leukocytes and bacteria in men with chronic prostatitis/chronic pelvic pain syndrome compared to asymptomatic controls. J Urol. 2003; 170:818-22. [PubMed: 12913707]

89. Breser ML, Motrich RD, Sanchez LR, Mackern-Oberti JP, Rivero VE. Expression of CXCR3 on specific $\mathrm{T}$ cells is essential for homing to the prostate gland in an experimental model of chronic prostatitis/chronic pelvic pain syndrome. J Immunol. 2013; 190:3121-33. [PubMed: 23455510]

90. Batstone GR, Doble A, Gaston JS. Autoimmune T cell responses to seminal plasma in chronic pelvic pain syndrome (CPPS). Clin Exp Immunol. 2002; 128:302-7. [PubMed: 12041509]

91. Kouiavskaia DV, Southwood S, Berard CA, Klyushnenkova EN, Alexander RB. T-cell recognition of prostatic peptides in men with chronic prostatitis/chronic pelvic pain syndrome. J Urol. 2009; 182:2483-9. [PubMed: 19765754]

92. Motrich RD, et al. Presence of INFgamma-secreting lymphocytes specific to prostate antigens in a group of chronic prostatitis patients. Clin Immunol. 2005; 116:149-57. [PubMed: 15993362]

93. Ponniah S, Arah I, Alexander RB. PSA is a candidate self-antigen in autoimmune chronic prostatitis/chronic pelvic pain syndrome. Prostate. 2000; 44:49-54. [PubMed: 10861757]

94. Alexander RB, Brady F, Leffell MS, Tsai V, Celis E. Specific T cell recognition of peptides derived from prostate-specific antigen in patients with prostate cancer. Urology. 1998; 51:150-7. [PubMed: 9457311]

95. Doble A, Walker MM, Harris JR, Taylor-Robinson D, Witherow RO. Intraprostatic antibody deposition in chronic abacterial prostatitis. Br J Urol. 1990; 65:598-605. [PubMed: 2196972]

96. Thumbikat $\mathrm{P}$, et al. Prostate secretions from men with chronic pelvic pain syndrome inhibit proinflammatory mediators. J Urol. 2010; 184:1536-42. [PubMed: 20723928]

97. Jung H, Toth PT, White FA, Miller RJ. Monocyte chemoattractant protein-1 functions as a neuromodulator in dorsal root ganglia neurons. J Neurochem. 2008; 104:254-63. [PubMed: 17944871]

98. Van Steenwinckel J, et al. CCL2 released from neuronal synaptic vesicles in the spinal cord is a major mediator of local inflammation and pain after peripheral nerve injury. J Neurosci. 2011; 31:5865-75. [PubMed: 21490228]

99. Koch AE, et al. Macrophage inflammatory protein-1 alpha. A novel chemotactic cytokine for macrophages in rheumatoid arthritis. J Clin Invest. 1994; 93:921-8. [PubMed: 8132778]

100. Koch AE, et al. Enhanced production of the chemotactic cytokines interleukin- 8 and monocyte chemoattractant protein-1 in human abdominal aortic aneurysms. Am J Pathol. 1993; 142:142331. [PubMed: 8494046]

101. Ikeda U, Matsui K, Murakami Y, Shimada K. Monocyte chemoattractant protein-1 and coronary artery disease. Clin Cardiol. 2002; 25:143-7. [PubMed: 12000070]

102. Nishimura T, et al. Study of macrophages in prostatic fluid from nonbacterial prostatitis patients. V. Relation between activation of macrophages and stage of prostatitis. Urol Int. 1991; 46:15-7. [PubMed: 2024364]

103. Zhang N, Rogers TJ, Caterina M, Oppenheim JJ. Proinflammatory chemokines, such as C-C chemokine ligand 3, desensitize mu-opioid receptors on dorsal root ganglia neurons. J Immunol. 2004; 173:594-9. [PubMed: 15210821]

104. Zhang N, et al. A proinflammatory chemokine, CCL3, sensitizes the heat- and capsaicin-gated ion channel TRPV1. Proc Natl Acad Sci U S A. 2005; 102:4536-41. [PubMed: 15764707]

105. Desireddi NV, et al. Monocyte chemoattractant protein-1 and macrophage inflammatory protein-1alpha as possible biomarkers for the chronic pelvic pain syndrome. J Urol. 2008; 179:1857-61. discussion 1861-2. [PubMed: 18353390]

106. White FA, Jung H, Miller RJ. Chemokines and the pathophysiology of neuropathic pain. Proc Natl Acad Sci U S A. 2007; 104:20151-8. [PubMed: 18083844]

107. Quick ML, et al. CCL2 and CCL3 are essential mediators of pelvic pain in experimental autoimmune prostatitis. Am J Physiol Regul Integr Comp Physiol. 2012; 303:R580-9. [PubMed: 22814670] 
108. Heninger AK, et al. IL-7 abrogates suppressive activity of human CD4+CD25+FOXP3+ regulatory $\mathrm{T}$ cells and allows expansion of alloreactive and autoreactive T cells. J Immunol. 2012; 189:5649-58. [PubMed: 23129754]

109. Sayed BA, Christy A, Quirion MR, Brown MA. The master switch: the role of mast cells in autoimmunity and tolerance. Annu Rev Immunol. 2008; 26:705-39. [PubMed: 18370925]

110. Walker ME, Hatfield JK, Brown MA. New insights into the role of mast cells in autoimmunity: evidence for a common mechanism of action? Biochim Biophys Acta. 2012; 1822:57-65. [PubMed: 21354470]

111. Kalesnikoff J, Galli SJ. New developments in mast cell biology. Nat Immunol. 2008; 9:1215-23. [PubMed: 18936782]

112. Metz M, Maurer M. Mast cells--key effector cells in immune responses. Trends Immunol. 2007; 28:234-41. [PubMed: 17400512]

113. Rao KN, Brown MA. Mast cells: multifaceted immune cells with diverse roles in health and disease. Ann N Y Acad Sci. 2008; 1143:83-104. [PubMed: 19076346]

114. Hallgren J, Pejler G. Biology of mast cell tryptase. An inflammatory mediator. FEBS J. 2006; 273:1871-95. [PubMed: 16640553]

115. Kim DY, Jeoung D, Ro JY. Signaling pathways in the activation of mast cells cocultured with astrocytes and colocalization of both cells in experimental allergic encephalomyelitis. J Immunol. 2010; 185:273-83. [PubMed: 20511559]

116. Sayed BA, Christy AL, Walker ME, Brown MA. Meningeal mast cells affect early T cell central nervous system infiltration and blood-brain barrier integrity through TNF: a role for neutrophil recruitment? J Immunol. 2010; 184:6891-900. [PubMed: 20488789]

117. Brenner T, Soffer D, Shalit M, Levi-Schaffer F. Mast cells in experimental allergic encephalomyelitis: characterization, distribution in the CNS and in vitro activation by myelin basic protein and neuropeptides. J Neurol Sci. 1994; 122:210-3. [PubMed: 7517440]

118. Yeh WI, McWilliams IL, Harrington LE. Autoreactive Tbet-positive CD4 T cells develop independent of classic Th1 cytokine signaling during experimental autoimmune encephalomyelitis. J Immunol. 2011; 187:4998-5006. [PubMed: 21984703]

119. Fletcher JM, Lalor SJ, Sweeney CM, Tubridy N, Mills KH. T cells in multiple sclerosis and experimental autoimmune encephalomyelitis. Clin Exp Immunol. 2010; 162:1-11. [PubMed: 20682002]

120. Murphy AC, Lalor SJ, Lynch MA, Mills KH. Infiltration of Th1 and Th17 cells and activation of microglia in the CNS during the course of experimental autoimmune encephalomyelitis. Brain Behav Immun. 2010; 24:641-51. [PubMed: 20138983]

121. Eller K, et al. IL-9 production by regulatory T cells recruits mast cells that are essential for regulatory T cell-induced immune suppression. J Immunol. 2011; 186:83-91. [PubMed: 21115728]

122. Steinman L. Multiple sclerosis: a coordinated immunological attack against myelin in the central nervous system. Cell. 1996; 85:299-302. [PubMed: 8616884]

123. Tanzola MB, Robbie-Ryan M, Gutekunst CA, Brown MA. Mast cells exert effects outside the central nervous system to influence experimental allergic encephalomyelitis disease course. $\mathrm{J}$ Immunol. 2003; 171:4385-91. [PubMed: 14530364]

124. Thompson AJ, et al. Patterns of disease activity in multiple sclerosis: clinical and magnetic resonance imaging study. BMJ. 1990; 300:631-4. [PubMed: 2138923]

125. Johnson D, Seeldrayers PA, Weiner HL. The role of mast cells in demyelination. 1. Myelin proteins are degraded by mast cell proteases and myelin basic protein and P2 can stimulate mast cell degranulation. Brain Res. 1988; 444:195-8. [PubMed: 2451996]

126. Piconese S, et al. Exacerbated experimental autoimmune encephalomyelitis in mast-cell-deficient Kit W-sh/W-sh mice. Lab Invest. 2011; 91:627-41. [PubMed: 21321538]

127. Lee DM, et al. Mast cells: a cellular link between autoantibodies and inflammatory arthritis. Science. 2002; 297:1689-92. [PubMed: 12215644]

128. Shin K, et al. Mast cells contribute to autoimmune inflammatory arthritis via their tryptase/ heparin complexes. J Immunol. 2009; 182:647-56. [PubMed: 19109198] 
129. Sawamukai N, et al. Mast cell-derived tryptase inhibits apoptosis of human rheumatoid synovial fibroblasts via rho-mediated signaling. Arthritis Rheum. 2010; 62:952-9. [PubMed: 20131259]

130. Hueber AJ, et al. Mast cells express IL-17A in rheumatoid arthritis synovium. J Immunol. 2010; 184:3336-40. [PubMed: 20200272]

131. Sandler C, et al. Selective activation of mast cells in rheumatoid synovial tissue results in production of TNF-alpha, IL-1beta and IL-1Ra. Inflamm Res. 2007; 56:230-9. [PubMed: 17607547]

132. Brown MA, Sayed BA, Christy A. Mast cells and the adaptive immune response. J Clin Immunol. 2008; 28:671-6. [PubMed: 18802742]

133. Hong GU, Kim NG, Jeoung D, Ro JY. Anti-CD40 Ab- or 8-oxo-dG-enhanced Treg cells reduce development of experimental autoimmune encephalomyelitis via down-regulating migration and activation of mast cells. J Neuroimmunol. 2013; 260:60-73. [PubMed: 23622820]

134. Piconese S, et al. Mast cells counteract regulatory T-cell suppression through interleukin-6 and OX40/OX40L axis toward Th17-cell differentiation. Blood. 2009; 114:2639-48. [PubMed: 19643985]

135. Forward NA, Furlong SJ, Yang Y, Lin TJ, Hoskin DW. Mast cells down-regulate CD4+CD25+ T regulatory cell suppressor function via histamine H1 receptor interaction. J Immunol. 2009; 183:3014-22. [PubMed: 19667094]

136. Ganeshan K, Bryce PJ. Regulatory T cells enhance mast cell production of IL-6 via surfacebound TGF-beta. J Immunol. 2012; 188:594-603. [PubMed: 22156492]

137. Rivero VE, Iribarren P, Riera CM. Mast cells in accessory glands of experimentally induced prostatitis in male Wistar rats. Clin Immunol Immunopathol. 1995; 74:236-42. [PubMed: 7859413]

138. Grimbaldeston MA, et al. Mast cell-deficient W-sash c-kit mutant Kit W-sh/W-sh mice as a model for investigating mast cell biology in vivo. Am J Pathol. 2005; 167:835-48. [PubMed: 16127161]

139. Palmer HS, et al. Protease-activated receptor 2 mediates the proinflammatory effects of synovial mast cells. Arthritis Rheum. 2007; 56:3532-40. [PubMed: 17968878]

140. Bali KK, et al. Transcriptional mechanisms underlying sensitization of peripheral sensory neurons by Granulocyte-/Granulocyte-macrophage colony stimulating factors. Mol Pain. 2013; 9:48. [PubMed: 24067145]

141. Okuse K. Pain signalling pathways: from cytokines to ion channels. Int J Biochem Cell Biol. 2007; 39:490-6. [PubMed: 17194618]

142. Thacker MA, Clark AK, Marchand F, McMahon SB. Pathophysiology of peripheral neuropathic pain: immune cells and molecules. Anesth Analg. 2007; 105:838-47. [PubMed: 17717248]

143. Pezet S, McMahon SB. Neurotrophins: mediators and modulators of pain. Annu Rev Neurosci. 2006; 29:507-38. [PubMed: 16776595]

144. Watanabe T, et al. Nerve growth factor level in the prostatic fluid of patients with chronic prostatitis/chronic pelvic pain syndrome is correlated with symptom severity and response to treatment. BJU Int. 2011; 108:248-51. [PubMed: 20883485]

145. Woolf CJ, Salter MW. Neuronal plasticity: increasing the gain in pain. Science. 2000; 288:17659. [PubMed: 10846153] 


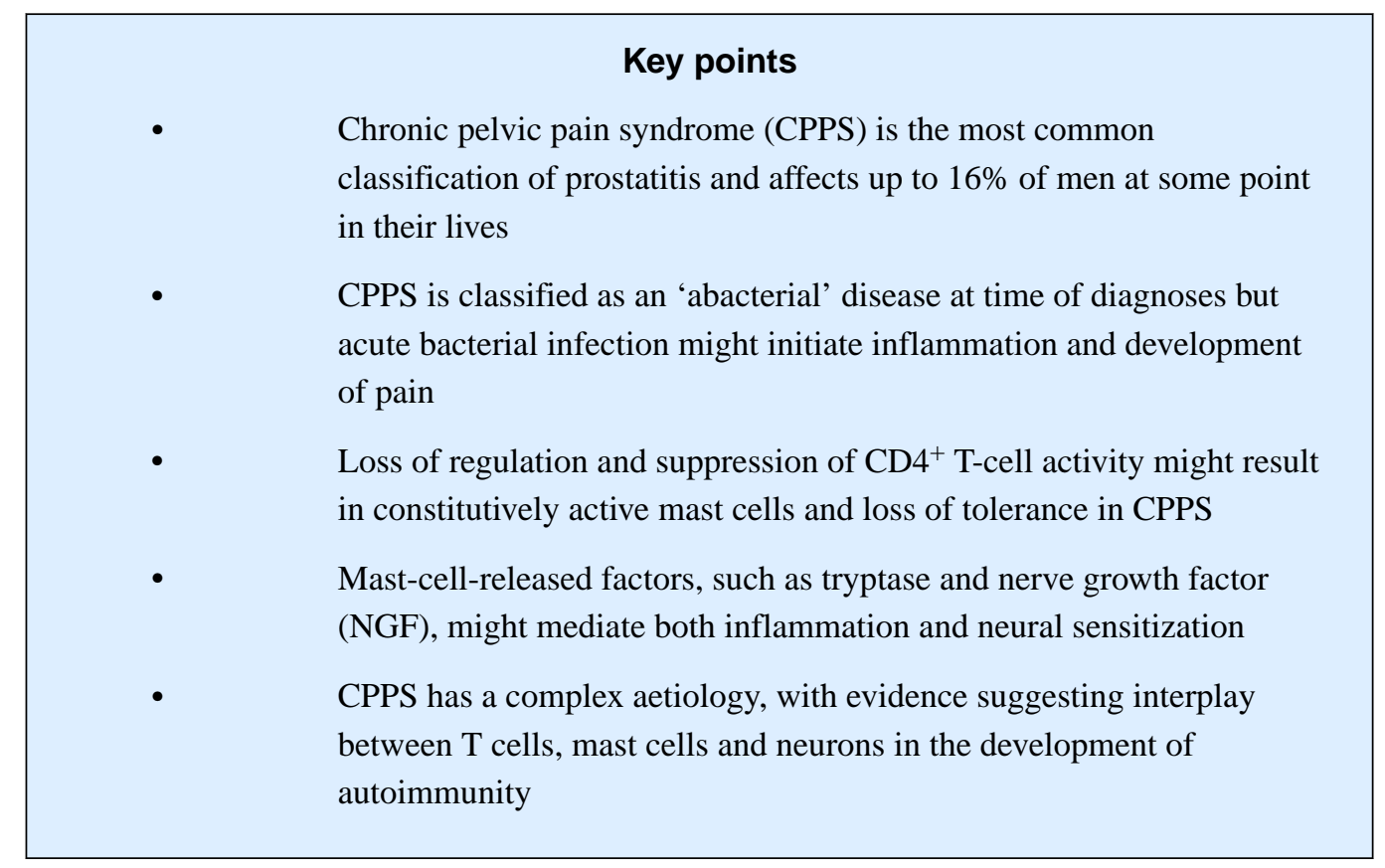


(A)
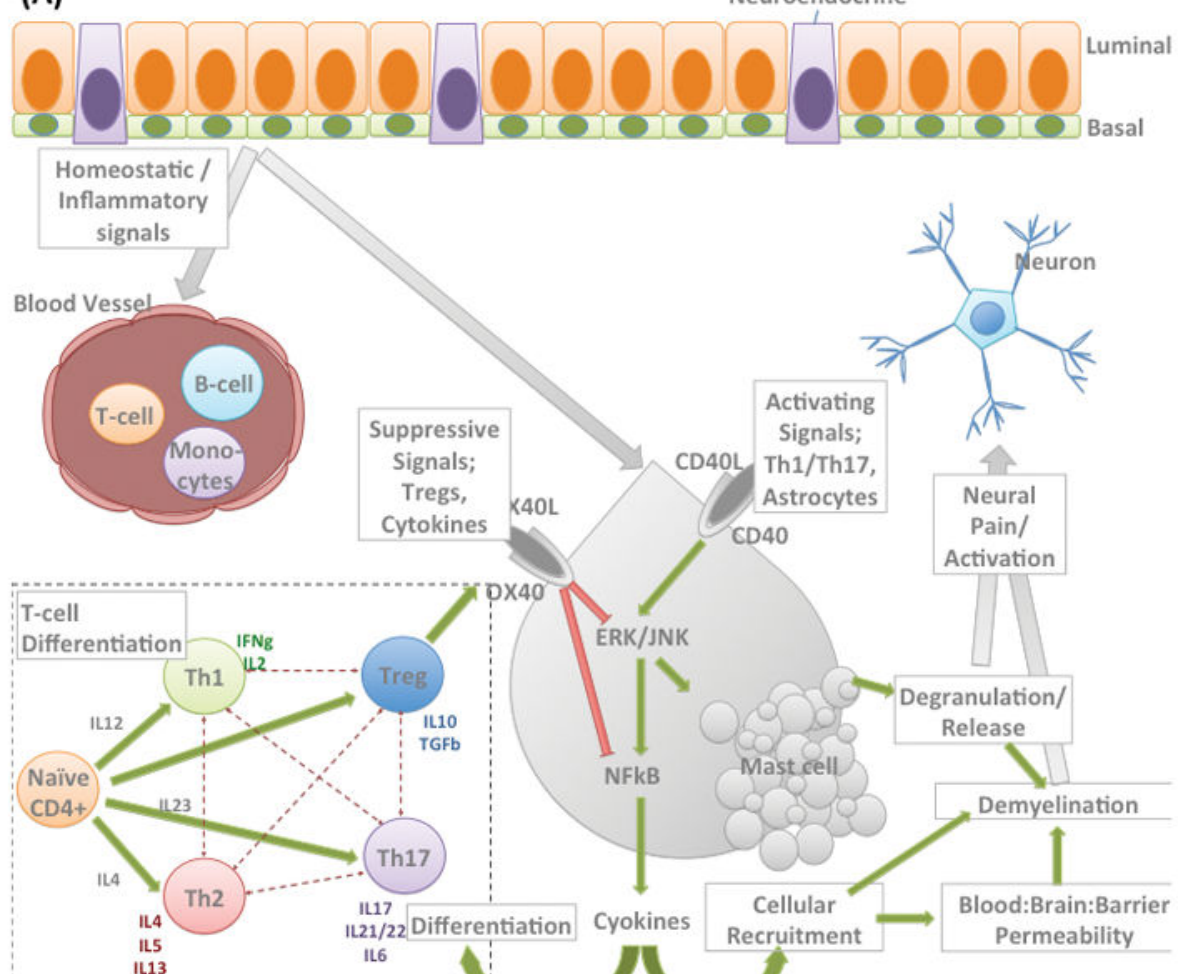

ERK/JNK

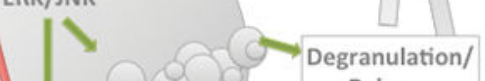
It1 IL6 


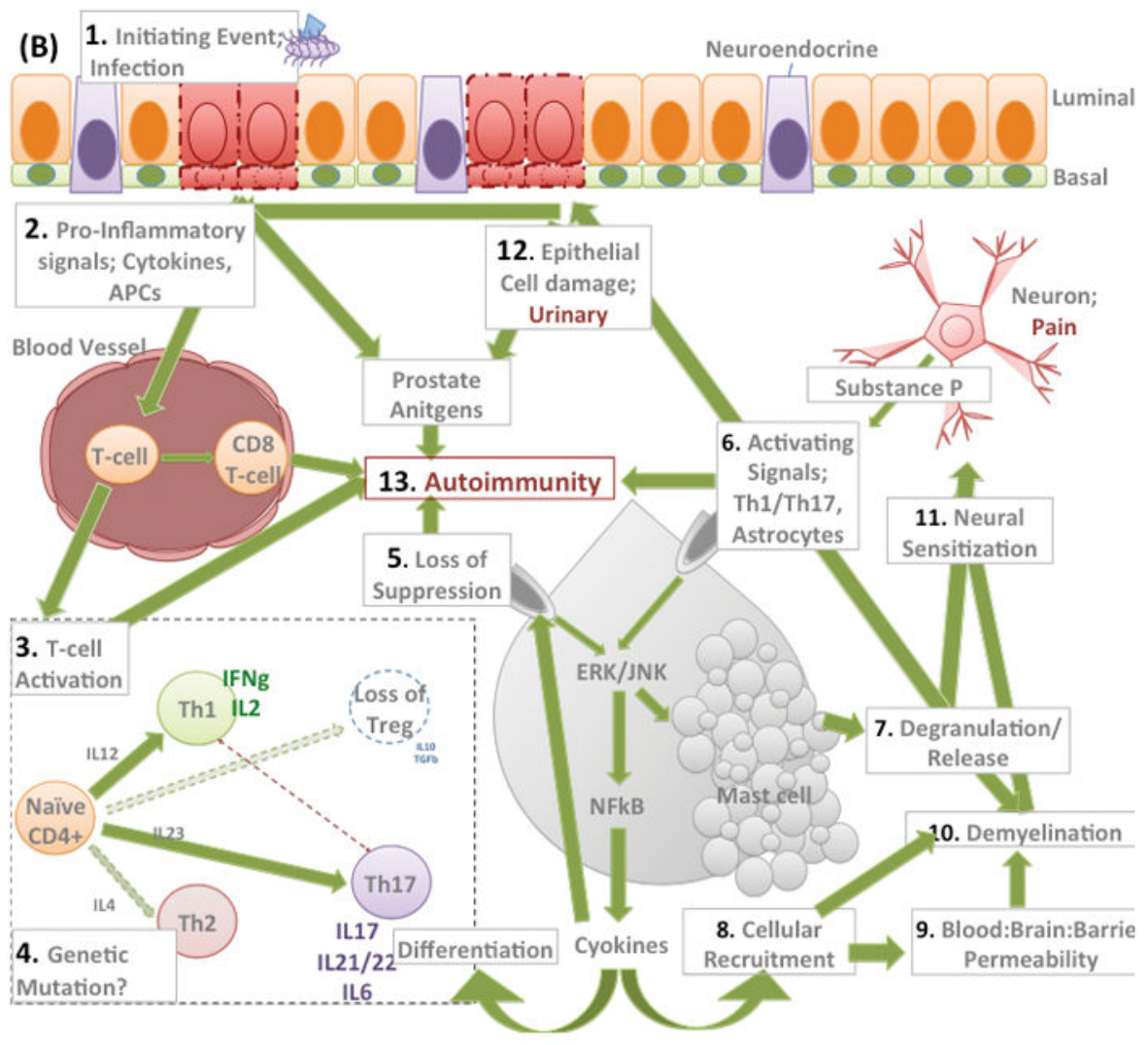

Figure 1. Hypothetical model of CPPS

(A) Intercellular homeostatic signaling demonstrating; differentiation of CD4 T-cells in a context dependent manner; Regulation of mast cell activation by direct interaction e.g. through OX40 receptor; Activation of Mast cells and subsequent deactivation. And how these signaling cascades interact to stimulate neurons. The system is tightly controlled and regulated with numerous checkpoints.

(B) Schematic representation of modulated immune system in CPPS. 1. We hypothesize that an initiating event, such as bacterial infection, drives prostatic epithelial cell damage and $\mathbf{2}$. Promotes secretion and activation of pro-inflammatory cytokines, chemokines and presentation of antigen via APCs 3. These signaling cascades result in CD4 T-cell activation which is initially of Th1-type (IFNgamma) but Th17 activation is also implicated in the pathway possibly at later stages of chronic pain development. 4. Data suggests a loss of IL-10 secreting suppressive T-regs and a skewing towards Th1/17 responses, this may be attributable to genetic polymorphisms regulating expression of these factors. 5. The loss of suppression of mast cells as a result of unchecked T-cell activation results in a positive feedback loop in the mast cell resulting in; 7. degranulation and releases of proteases such as tryptase, chymase and allergy mediators such as histamine., and 8. cytokine secretion (IL6, IL17, TNFa, IL6) resulting in recruitment of inflammatory cells. Together 7. and 8. can disrupt the Blood Brain Barrier, 9. and/or directly 10. demyelinate neurons. Taken together these processes result in 11. neuronal activation and sensitization. The mast cell mediates these events and positive feedback loops increase these processes through $\mathbf{6}$. Further epithelial cell damage, 12., is one consequence of such increased mast cell activity. Prostate 
antigens generated from damage to the epithelium in the presence of an activated CD4 T-cell response, with unchecked mast cell degranulation and increased numbers of CD8 Tcells can result in development of 13. autoimmunity, which only further exacerbates these mechanisms. 